other Mohammedan countries ; but she has wisely relegated them to footnotes in order not to blur the picture given in the text.

Most of Dr. Granquist's information was obtained from two native women recommended to her by Miss Louise Baldensperger, whose knowledge of Arțās, where she had lived more than thirty years, was "of inestimable help and value" to the author. Those two informants learned to relate so slowly that their statements could be taken down word for word. The material is thus to a large extent a direct translation of the literal reports given by the women, but very frequently the translation is followed by the Arabic original. This is particularly the case with the copious songs, proverbs and formulæ found in the text, which, consequently, also should make the book a valuable contribution to Arabic dialectology.

The importance of Dr. Granqvist's investigations is enhanced by the fact that they have been made by a woman among women. In a society where the sexes are so secluded from each other as they are in the Mohammedan world, I think that the women can be properly studied only by members of their own sex ; but in most cases the writers on Mohammedan marriage customs have been men. The author writes that those who have women as informants are in a specially favoured position, because "the women are very much interested in their conditions and linger with pleasure over things which the men glide over lightly". But as marriage is an institution in which both sexes are concerned, I also think that there are aspects of it which can be properly studied only by men.

A Mohammedan marriage is a complicated procedure, and Dr. Granqvist gives a graphic description of its successive stages. She has chapters on the age of marriage and child betrothal; the choice of a bride ; the exchange of bride for bride and the bride price ; the betrothal ceremonies and the making of the marriage contract ; preparations for the wedding; the fetching of the bride; her arrival in the bridegroom's house; and the wedding week. There are chapters on the married woman in her husband's house and on her relation to her father's house, which are the more interesting since they deal with subjects that have not generally been sufficiently noticed in the literature on Mohammedan marriages. A woman is even after her marriage closely bound to her father's house, and her position in her husband's house is dependent on the esteem she enjoys and the support she can count upon in her old home. In critical situations she takes refuge there; when she is dissatisfied with the manner in which her husband treats her or when she is divorced by him. So also she is protected by her brother: "a man is even more responsible for his sister than for his wife and children".

The people themselves are said to find with surprise how well marriage generally turns out. Polygyny is certainly a disturbing factor; there is a saying that "the co-wife is bitter even if she were honey in a jar". But polygyny is not frequent in Artas, and in one great clan altogether lacking. A reason for this is the deficiency of women, which has compelled many men to take wives from other places. The author raises the question whether this deficiency may be due to the high percentage of cousin marriages, in accordance with my finding that in various cases inbreeding is combined with an excess of males. Thus, according to statistics of 1901, the small community of Samaritans at Nablus, who never marry outside of their own body, consists of 97 males and 55 females. Divorce is even less frequent in Artās than polygyny, which is contrary to the opinions generally held about Mohammedan peoples. While of the 199 married men 26 are or have been polygynous, only 10 have divorced their wives. The author admits that the infrequency of divorce is probably connected with the poverty of the village and the small number of women, but thinks available statistics would prove that the prevalence of divorce in the Mohammedan world has been greatly exaggerated. This is an altogether exceptional case in which Dr. Granqvist's study of the little Palestinian village has led her to such far-reaching speculations. A chapter on widower and widow concludes her remarkable book, which also contains excellent illustrations from photographs taken by the author.

Edward Westermarck.

\section{Die Fermente und ihre Wirkungen}

Von Prof. Carl Oppenheimer. Supplement. Lief. 5. (Band 1: Specieller Teil: Haupt-Teil 12.) Pp. xii +641-78l. (Den Haag: Dr. W. Junk, 1936.) 10 fl.

THe fifth delivery of this supplement continues the description of those enzymes which attack proteins, namely, the proteases and peptidases. It commences with two chapters of particular and general interest, one containing a discussion of some special questions relating to protein structure and the other being devoted to the question of the simplification of the true proteins by these enzymes. Both are of considerable value at the present time, when so much is uncertain in this intricate field of knowledge, and their study, though far from easy, will be helpful for those workers who are trying to bring some clarity into the subject.

The proteases are described in some detail under the headings of their qualitative and quantitative detection and their separation. About half the volume is devoted to the properties of the peptidases from a number of different aspects. 